\title{
ReSEARChArticle
}

\section{Effect of pollen viability and method of storage on seed set, seed yield and seed quality under in-vivo condition of sunflower}

\author{
V. K. DESHPANDE AND PRIYA KIVADASANNAVAR
}

\section{SUMMARY}

In vivo pollen viability studies revealed that there was no significant difference with 100 per cent fresh pollen (61.98) and combination of 75 per cent pollen +25 per cent mixture and same either as fresh or stored in refrigerator and earthen pot for one day. Application of pollens stored under ambient condition for one day resulted in poor seed set i.e. 41.07 to 45.58 per cent. Seed yield as measured setting percentage and 100 seed weight were maximum with cent per cent pollen either as fresh or refrigerator and earthen pot storage. Lower values were recorded in pollen stored at ambient condition for one day.

Key Words : Pollen storage, Filler mixture, In vivo, Sunflower

How to cite this article : Deshpande, V.K. and Kivadasannavar, Priya (2016). Effect of pollen viability and method of storage on seed set, seed yield and seed quality under in-vivo condition of sunflower. Internat. J. Plant Sci., 11 (2): 318-321, DOI: 10.15740/HAS/IJPS/ 11.2/318-321.

Article chronicle : Received : 28.12.2015; Revised : 21.05.2016; Accepted : 22.06.2016

\section{MEMBERS OF THE RESEARCH FORUM}

Author to be contacted :

PRIYA KIVADASANNAVAR, Department of Seed Science and Technology, College of Agriculture, University of Agricultural Sciences, DHARWAD (KARNATAKA) INDIA

Email: Priya.bk@rediffmail.com

\section{Address of the Co-authors:}

V. K. DESHPANDE, Department of Seed Science and Technology, College of Agriculture, University of Agricultural Sciences, DHARWAD (KARNATAKA) INDIA

Email: vkd1@rediffmail.com; vkdesh12@gmail.com 